\title{
International Law Rules on Treaty Interpretation
}

\author{
STEVEN R RATNER
}

\subsection{Introduction}

International law is central to the interpretation of both of the Brexitrelated treaties. The Trade and Cooperation Agreement (TCA) explicitly requires the parties and any dispute settlement body to interpret it according to the rules of interpretation of public international law, notably the 1969 Vienna Convention on the Law of Treaties (VCLT). The Withdrawal Agreement (WA), and thus the Protocol, by specifying that any of its provisions concerning Union law or concepts must be interpreted in accordance with EU law (including the case law of the Court of Justice of the European Union (CJEU)), implies that its many provisions not concerning EU law will need to be interpreted by the default rules of treaty interpretation, namely those of the VCLT. This chapter provides a brief overview of those rules and some of their implications for these two instruments. I focus on Articles 31 and 32 of the VCLT that concern the interpretation of treaties.

\subsection{Parsing the TCA and WA Provisions on Interpretation}

TCA Article 4(1) states:

The provisions of this Agreement and any supplementing agreement shall be interpreted in good faith in accordance with their ordinary meaning in their context and in light of the object and purpose of the agreement in accordance with customary rules of interpretation of public international law, including those codified in the Vienna Convention on the Law of Treaties, done at Vienna on 23 May 1969.

The following two paragraphs add, 'for greater certainty', that parties are not obliged to interpret the agreement in accordance with their domestic law; and that an interpretation by the courts of either party shall not bind the courts of the other party. 
The first sentence of Article 4(1) WA begins with language nearly identical to the key sentence in Article 31 VCLT: 'A treaty shall be interpreted in good faith in accordance with the ordinary meaning to be given to the terms of the treaty in their context and in light of its object and purpose.' But Article 4(1) then clarifies (or perhaps conditions) this phrase by adding that such interpretation must be 'in accordance with' customary international law, including the VCLT. The choice of words is odd, but not unique, as it appears in a number of EU treaties with nonEU states. ${ }^{1}$ It refers to customary international law directly, and the VCLT secondarily, as (a) the EU itself is not a party to the VCLT; (b) the VCLT does not govern treaties between international organizations and states; and (c) customary international law includes other rules of interpretation (discussed in Sections 7.5 and 7.7) not mentioned in the VCLT. Nevertheless, the TCA accepts - as is universally accepted - that the VCLT's rules of interpretation are customary international law. ${ }^{2}$

The WA, for its part, contains the following two paragraphs in Article 4:

3. The provisions of this Agreement referring to Union law or to concepts or provisions thereof shall be interpreted and applied in accordance with the methods and general principles of Union law.

4. The provisions of this Agreement referring to Union law or to concepts or provisions thereof shall in their implementation and application be interpreted in conformity with the relevant case law of the Court of Justice of the European Union handed down before the end of the transition period.

From the language of these paragraphs, provisions of the WA that do not refer to EU law, concepts or provisions will not be governed by EU law and CJEU jurisprudence. What, then, will be the framework for their interpretation? The WA cannot mean that non-EU law provisions would be interpreted solely in accordance with the law of one or the other party. The only alternative principles for interpreting any treaty - whether between states or between the EU and a state - are those of public international law. The public international law that applies is essentially

${ }^{1}$ See, eg, Comprehensive Economic and Trade Agreement between the European Union and Canada, 30 October 2016, Art 29.17; Free Trade Agreement between the European Union and the Socialist Republic of Viet Nam, 12 June 2020, Art 15.21.

2 The 1986 Vienna Convention between States and International Organizations or between International Organizations is not in force, though it contains the same rules of treaty interpretation. 
that set forth in the TCA, namely customary international law, including the VCLT.

\subsection{The VCLT's Rules of Interpretation: General Themes}

Article 31 is a sort of bible when it comes to treaty interpretation. Global, regional and domestic courts routinely cite it as providing the framework for the treaties they interpret. Before delving into the key provisions and their implications for the Brexit agreements, a few key points should be made:

(i) The goal of treaty interpretation under the VCLT is to determine the meaning of the treaty viewed from the perspective of the contemporary shared understanding of the parties to the treaties. As James Crawford has pointed out, from the perspective of international law, 'the parties ... own the treaty', ${ }^{3}$ even if it is certainly the case that their citizens, animals and plants (and those of other states) may well be affected by how that treaty is interpreted. As a result, the key evidence for interpretation will be the interactions of the parties insofar as it demonstrates that shared understanding.

(ii) Treaty interpretation is not just a task for tribunals. Parties to treaties are constantly interpreting them, making claims against the other party in diplomatic settings, bilaterally and multilaterally, confidentially and publicly. Only a small handful of these disputes will make it to tribunals due to jurisdictional obstacles and incentives that states have to avoid formal dispute settlement. Yet the provisions remain relevant nonetheless.

(iii) Although the VCLT's rules of interpretation are laid out in two articles, treaty interpretation is not a formulaic exercise, where boxes are checked and then a decision reached. Moreover, although various indicia of the meaning of the text appear in Articles 31 and 32, the VCLT does not offer a ranking of evidence, insofar as a meaning flowing from one set of evidence will simply override that flowing from recourse to other evidence - with the one obvious exception that the text obviously 'counts' more than anything else. At the same time, there is a general understanding among tribunals

3 James Crawford, 'A Consensualist Interpretation of Article 31(3) of the Vienna Convention on the Law of Treaties' in Georg Nolte et al (eds), Treaties and Subsequent Practice (Oxford University Press 2013) 29, 31. 
that some evidence will be more probative of the parties' contemporary understanding than others. ${ }^{4}$

(iv) Treaty interpretation, like statutory interpretation, can easily yield more than one convincing interpretation of a treaty. Just as the states parties to a treaty may have bona fide differences of opinion regarding its meaning, so may judges. At the same time, the tools of treaty interpretation generally succeed in narrowing the range of plausible interpretations, sometimes to one.

(v) The VCLT's rules for treaty interpretation are default rules. The parties to a treaty are free to include clauses in the treaty, or in subsequent instruments, that offer (a) a particular interpretation of a clause, (b) a particular set of indicia to consider or exclude in future interpretations and (c) a specific process for interpretation that may differ from that in the VCLT.

(vi) Relatedly, different tribunals have developed interpretive methodologies that are distinct from those in the VCLT, or at least put a particular emphasis on one factor more than others. Notably, both the European Court of Human Rights (ECtHR) and the CJEU have endorsed a broadly teleological approach to treaty interpretation that emphasizes the overall purposes of the European human rights regime or the EU, respectively. In addition, the ECtHR has developed at least one doctrine, the margin of appreciation, that is certainly not part of the VCLT (though it is not precluded by the VCLT either).

(vii) While the VCLT does not include an explicit obligation on domestic courts to employ it to interpret treaties, it is, of course, a treaty itself, binding on the states parties (which include the UK). So, depending on each state party's approach to the direct application of treaties (eg, monist versus dualist), domestic courts will have a domestic law obligation to interpret the treaty in accordance with the VCLT. ${ }^{5}$

${ }^{4}$ See Jean-Marc Sorel and Valérie Boré Eveno, 'Article 31: General Rule of Interpretation' in Olivier Corten and Pierre Klein (eds), The Vienna Convention on the Law of Treaties: A Commentary, Vol. 1 (Oxford University Press 2011) 804, 829.

5 The Agreements clearly foresee a role for Northern Ireland courts, in WA Arts 4, 158, 159 and 162; and the TCA's general provision barring direct actions by individuals to enforce it excludes provisions on law enforcement co-operation (Art 5(1)). See generally David Sloss, 'Domestic Application of Treaties' in Duncan Hollis (ed), The Oxford Guide to Treaties (Oxford University Press 2012) 367. 


\subsection{The Starting Point: Text, Object and Purpose, and Context}

The VCLT's first command to a treaty interpreter appears in Article 31(1) and (2):

1. A treaty shall be interpreted in good faith in accordance with the ordinary meaning to be given to the terms of the treaty in their context and in the light of its object and purpose.

2. The context for the purpose of the interpretation of a treaty shall comprise, in addition to the text, including its preamble and annexes: (a) any agreement relating to the treaty which was made between all the parties in connexion with the conclusion of the treaty; (b) any instrument which was made by one or more parties in connexion with the conclusion of the treaty and accepted by the other parties as an instrument related to the treaty.

These two articles provide a text-based starting point for treaty interpretation. In the case of the TCA, the text includes all its protocols, annexes, appendices and footnotes. ${ }^{6}$ In the case of the WA, the three Protocols and the nine Annexes are all part of the text. ${ }^{7}$ While the VCLT refers only to the 'ordinary meaning [of] the terms of the treaty', tribunals have relied on additional doctrines, which can be said to constitute customary international law, to engage more meaningfully with the text. Various principles from domestic law, such as ejusdem generis and expressio unius est exclusio alterius, are frequently borrowed. The principle of effectiveness, or effet utile, is particularly worth mentioning. This principle requires that a treaty is to be interpreted to give it, as a whole, and the individual provisions within it meaningful effect. The approaches of international courts reveal that the principle of effet utile means that treaty clauses must be interpreted to avoid either rendering them superfluous or depriving them of significance for the relationship between the parties. ${ }^{8}$

As for the 'object and purpose', tribunals have significant discretion in their mode of determining it, as well as its impact on the meaning of the text. Often the text will specify the agreement's purpose, either in the preamble or in an early article. The TCA does so in its very lengthy preamble as well as its rather anodyne Article 1; the WA also has

6 TCA Art 778.

7 WA Art 182.

${ }^{8}$ Case Concerning Application of the International Convention on the Elimination of All Forms of Racial Discrimination (Georgia v Russia), Preliminary Objections, 2011 ICJ Rep. 70, para 134; Sorel and Eveno (n 4) 830-32. 
a lengthy preamble and similar Article 1 . However, the Protocol has not only a lengthy preamble but a much more specific Article 1: it clarifies that the Protocol is 'without prejudice' to the 1998 Agreement; that it respects UK 'essential State functions and territorial integrity'; and that its arrangements address 'unique circumstances on the island of Ireland', 'maintain the necessary conditions for continued North-South cooperation', 'avoid a hard border' and 'protect the 1998 Agreement in all its dimensions'. These clauses clearly inform the interpretation of the Protocol and the WA generally. ${ }^{9}$

The 'context' of the treaty is, in a sense, more concrete, as it consists of other written instruments concluded in connection with the treaty. They must be written, agreed upon, 'relating to the treaty' and 'in connection with the conclusion of the treaty'. Typical examples include exchanges of notes between the parties that define terms or include additional commitments. For the TCA and the WA, no simultaneous agreements or exchanges of notes were agreed at the time of their conclusion. At the same time, the term 'in connection' does not have a fixed time-limited meaning, so even though more than a year separated the conclusion of the TCA and that of the WA, courts may need to decide whether the WA is part of the context of the TCA as well as whether the TCA is part of the context of the WA. The 'Political Declaration' agreed in November 2018 might also be such an instrument ${ }^{10}$ (though it might also be part of the negotiating history for purposes of Article 32 of the VCLT).

\subsection{Role of Subsequent Agreements, Practice and Other Rules of International Law}

Article 31(3) of the VCLT begins an additional list of indicia for interpreters beyond the immediate context of the conclusion of the treaty (a list that continues in Article 32, discussed in Section 7.6 of this chapter):

There shall be taken into account, together with the context: (a) any subsequent agreement between the parties regarding the interpretation

9 As one small example of the difficulties in determining object and purpose, in Australia's ICJ case against Japan over whaling, Australia claimed that the purpose of the treaty was to protect whales, while Japan argued that it was to regulate whaling and preserve the whaling industry. In the end, the Court found both to be purposes of the treaty, though neither purpose did much work in its ultimate interpretation of the text. Whaling in the Antarctic (Australia v Japan, NZ Intervening), 2014 ICJ Rep. 224 (14 March 2014), paras 55-58.

10 'Outline of the Political Declaration Setting Out the Framework for the Future Relationship between the European Union and the United Kingdom', 14 November 2018. 
of the treaty or the application of its provisions; (b) any subsequent practice in the application of the treaty which establishes the agreement of the parties regarding its interpretation; (c) any relevant rules of international law applicable in the relations between the parties.

The first two additional elements concern the way that the parties understand the meaning of the treaty since its entry into force. Subsequent agreements (a) refer to new treaties or other agreements (eg, oral agreements) where the parties clarify how they wish to interpret or apply the treaty. Such agreements are given significant, even dispositive, weight because they clearly demonstrate the parties' contemporaneous understanding of the meaning of a treaty. In the case of the TCA and the WA, such agreements are certainly possible. Indeed, the TCA itself presumes that such agreements will be 'supplementing agreements' that will be an 'integral part of the overall bilateral relations ... and shall form part of the overall framework'. ${ }^{11}$ The TCA does not quite call these supplementary agreements an integral part of the TCA text itself, but it suggests that future interpreters using VCLT Article 31(3)(a) should give them heavy weight.

The second interpretive aid, subsequent practice (b), is also very important but much more difficult to identify because it is typically not reduced to a single document. Interpreters have to verify that the two (or more) parties are truly agreed on what a particular provision of the treaty means, as opposed to simply agreeing on something else. ${ }^{12}$ In recent years, the UN's International Law Commission (ILC) has offered detailed guidance to states and courts about the meaning of subsequent practice. That guidance clarifies that the range of acts that might constitute subsequent practice includes executive, legislative, judicial or other acts of the parties (but not of non-state actors), as a well as a conference, or joint institution, of the parties. ${ }^{13}$ So if, for instance, the highest domestic

11 Art 2 TCA.

12 One classic example of states giving great weight to subsequent practice concerns Art 27(3) of the UN Charter: 'Decisions of the Security Council on all other matters shall be made by an affirmative vote of nine members including the concurring votes of the permanent members ....' When the UN's members began treating an abstention by a member of the permanent five as equivalent to a 'concurring vote' - which they did the first time it was used in 1946 - the meaning of that term was no longer in doubt; textual or other arguments that 'concurring' meant 'affirmative' simply did not matter (including to the ICJ). Legal Consequences for States of the Continued Presence of South Africa in Namibia (South West Africa) notwithstanding Security Council Resolution 276 (1970), 1971 ICJ Rep. 16 (Advisory Opinion of 21 June), para 22.

13 ILC, Draft conclusions on subsequent agreement and subsequent practice in relation to the interpretation of treaties, conclusion 5-6, 11(3), 12(2), in Report of the International Law Commission, Seventieth Session, UN Doc A/73/10, at 12 (2018). 
courts of the two parties to a treaty explicitly shared an understanding of a term in the treaty, and that understanding was not contradicted by other organs of the state, those court judgments would constitute the sort of state practice that is to be taken into account under sub-paragraph (b). If one of the many bilateral institutions established under the WA and the TCA, from the highest political level to the expert/technical level, were to agree on an interpretation of the treaties, that too would be important subsequent practice. ${ }^{14}$

The third interpretive aid, other relevant rules of international law applicable in the relations of the parties (c), on its face opens the door to courts interpreting either the WA or the TCA to bring in completely extraneous treaties - whether human rights, environmental law, the law of the sea, international trade law (including intellectual property) - as well as rules of customary international law. Much of this process is not controversial. For example, international courts routinely rely on the customary law rules of state responsibility to determine when an action in violation of a treaty is imputable to one of the parties. ${ }^{15}$ So, too, may international courts sometimes rely on an obviously relevant treaty for the purpose of interpreting another treaty, such as interpreting the term 'territorial sea' by reference to the UN Convention on the Law of the Sea.

But hard cases abound, where the parties or judges may have to interpret whether a particular norm is a 'rule', whether it is 'relevant' and whether it is 'applicable in the relations between the parties'. ${ }^{16}$ If one party to a dispute believes that a treaty should be interpreted in light of another treaty to which only one of the states is party, it would be hard to view that second treaty as 'applicable' (unless the rule in it has become one of customary law). In the case of the Protocol, two obviously delicate questions will concern whether the 1998 Agreement and the ECHR fit within Article 31(3)(c). The former is mentioned numerous times in the Protocol, with an emphasis on the need to preserve its operation; ${ }^{17}$ but the EU is not a party to it. Nor is the EU a party to the ECHR, although all members of the EU are party to that treaty. Courts might nonetheless

14 See, eg, Whaling in the Antarctic, para 83.

15 See, eg, Application of the Convention on the Prevention and Punishment of the Crime of Genocide (Bosnia v Serbia), 2007 ICJ Rep. 43 (26 February), paras 385, 398.

16 For one useful study, see Bruno Simma and Theodore Kill, 'Harmonizing Investment Protection and International Human Rights: First Steps towards a Methodology' in $\mathrm{C}$ Binder et al (eds), International Investment Law for the 21st Century: Essays in Honour of Christoph Schreuer (Oxford University Press 2009) 678.

17 Eg, Protocol Preamble paras 4-5, Arts 1(3), 2. 
look past these distinctions and determine that both are indeed 'relevant' and 'applicable'. Regarding the TCA, Part 3 on criminal law enforcement co-operation states that the co-operation is 'based on' the ECHR and the importance of giving it domestic effect, and that nothing in the TCA modifies the duty to respect the rights in the ECHR. ${ }^{18}$ So clearly the ECHR constitutes a relevant rule for purposes of interpreting Part 3.

\title{
7.6 Supplementary Means
}

The VCLT's other article on interpretation invites tribunals to consider what are deemed 'supplementary' indicia:

\begin{abstract}
Recourse may be had to supplementary means of interpretation, including the preparatory work of the treaty and the circumstances of its conclusion, in order to confirm the meaning resulting from the application of article 31 , or to determine the meaning when the interpretation according to article 31: (a) Leaves the meaning ambiguous or obscure; or (b) Leads to a result which is manifestly absurd or unreasonable.
\end{abstract}

Although Article 32 begins with the word 'may', its drafters fully expected tribunals to refer to these materials, and many tribunals routinely have recourse to supplementary materials, in particular the negotiating history of a treaty (travaux préparatoires). ${ }^{19}$ As the text makes clear, tribunals are not constrained in when they may turn to these supplementary means, as they can be used to either confirm or rebut what has been found from the deployment of Article 31. Yet the travaux, especially of a particular article in a treaty, may be obscure. The deal on the language may have been reached over drinks or coffee at a bar, or just in a conversation off the record, so that those taking notes of the negotiation never wrote down what the parties meant to agree on - or to avoid agreeing on. The negotiating history could be confidential, requiring an interpreting body to request it from the parties. This uncertainty over the availability and reliability of the travaux préeparatoires, combined with a view that these materials should matter less than those showing the contemporaneous understanding of the parties, may render them ultimately of little use for interpreting some treaties, though tribunals take them into account when they can find them.

18 TCA Art 524.

19 Richard Gardiner, 'The Vienna Convention Rules on Treaty Interpretation' in Duncan Hollis (ed), The Oxford Guide to Treaties (Oxford University Press 2012) 475, 479-80, 487-89. 
Article 32 is not limited to the preparatory work of the treaty. It includes any other material related to the conclusion of the treaty not covered in Article 31(2), including statements by the negotiators to their legislature during debates over the latter's approval of the treaty. In addition, as the ILC has recently made clear, it includes the conduct of one or all parties to the treaty when that practice does not demonstrate the agreement of the parties required for that practice to be considered under Article 31(3)(b). ${ }^{20}$ So courts might look at the interpretation of the treaties by the parties to demonstrate that a particular understanding is not shared.

In the case of the WA, some of the negotiating record is easily available - notably the first EU Commission proposed draft, as well as the EU-UK agreed draft rejected by Parliament; other documents are public. The statements of the negotiators to their legislatures are well documented; and both treaties have been the subject of disagreements already. Notably, the EU accused the UK of breaching the WA, including its duty of good faith, ${ }^{21}$ in including a particular clause (later withdrawn) in a bill introduced in Parliament, and in delaying certain customs regulations on goods destined for Northern Ireland. ${ }^{22}$

\subsection{Conflicts: Peremptory Norms and Other Treaties}

While international law gives states virtually unlimited discretion to define, refine, alter and terminate their treaty relations, this discretion is not completely unlimited. Article 53 treats as void ab initio any treaty conflicts with a norm of jus cogens. Certainly, civil society actors like to make claims that various parts of treaties so conflict, rendering the treaties void. Yet the scope of jus cogens norms is extremely limited - the ban on the use of force, a few core human rights norms (the ban on genocide, torture or crimes against humanity), the supremacy of the UN Charter, and perhaps a few others. It seems highly unlikely that any provision of the WA or the TCA would violate jus cogens.

A separate question is whether an obligation under either treaty might conflict with another treaty or rule of customary international law, insofar as carrying it out would breach those other rules. In this

${ }^{20}$ ILC Draft Conclusions, conclusion 4-5.

${ }^{21}$ Art 5 WA.

22 See Chapter 5. 
scenario, there are various possible responses: the states will amend the treaty to avoid the conflict; one or both will interpret it through recourse to Article 31(c)(3) to avoid the conflict (although conceivably the parties could interpret it differently); or the parties will need to assume the consequences of a breach of the other rule. The VCLT does not set any priorities for treaties nor require that one treaty be interpreted to be consistent with another (although the text of a particular treaty can so provide). So, international law does not require that the WA or the TCA be interpreted to be consistent with something as old as the Act of Union of 1800 unifying Ireland and Great Britain (eg, its provisions on commerce), or something as recent as the WTO Agreements. In addition, Article 30 of the VCLT provides that if the parties to one treaty later conclude another treaty on the same subject matter without terminating the first, the earlier treaty applies only to the extent that it is 'compatible' with the later treaty, unless the parties specify otherwise. ${ }^{23}$

\subsection{Conclusion}

Articles 31 and 32 VCLT are central to the interpretation of all treaties and are routinely applied by international, regional and domestic courts and arbitral bodies - and of course by treaty parties themselves in their interactions regarding the implementation of treaties. They are the subject of enormous case law and scholarship; the aim of this chapter has been only to highlight their key features when it comes to the Brexit agreements. ${ }^{24}$ What remains to be seen is how the different courts and tribunals that engage with the Brexit agreements (domestic courts, the CJEU, the arbitration panels) may use the VCLT, perhaps, in different ways. The CJEU has significant experience using

${ }^{23}$ See, in this context, In the matter of an Application by Allister, et al [2021] NIQB 64 (per Colton, J), paras 63-114 (finding that Withdrawal Acts implementing the Brexit agreements override the Act of Union); see also ibid, paras 64-66 (rejecting the claim of invalidity of the WA under the VCLT).

24 Beyond the VCLT's rules on treaty interpretation, several other provisions may at some stage prove relevant to the interpretation and application of the WA and the TCA: Art 26 (all parties to carry out their treaty obligations in 'good faith') - see Chapter 8; Art 60 allowing treaty suspension or termination following a 'material breach' by the other party - see Chapter 25; and Art 62 permitting treaty suspension or termination in the event of a 'fundamental change in circumstances' (rebus sic stantibus) - see Chapter 25. 
the interpretive methodology of the VCLT in interpreting treaties between the EU and other states (while adopting a sui generis framework for interpreting the EU's constitutive instruments). Yet, as numerous commentators have noted, even as it applies the VCLT framework, its approach is often quite idiosyncratic. ${ }^{25}$

25 For example, it has an expansive notion of the idea of the object and purpose of a treaty, extending the teleological approach it uses to interpret the EU's constitutive acts to other treaties. Jed Odermatt, 'The Use of International Treaty Law by the Court of Justice of the European Union' (2015) 17 Cambridge Yearbook of European Legal Studies 121. 